\title{
Phytochemical, Antimicrobial and Sensory Qualities of Herbal Tea Made from Sarcandra glabra and Drymis piperita
}

\author{
MA. Louisa G. Taguiling ${ }^{1}$ and Chita Villena ${ }^{2}$ \\ ${ }^{1,2}$ Ifugao State University, Nayon, Lamut, Ifugao, Philippines (corresponding author's phone: +639068668900; \\ e-mail: naptag@yahoo.com).
}

\begin{abstract}
An herbal tea was formulated in order to maximize health benefits derived from Sarcandra glabra and Drymis piperita, known in many countries as medicinal plants and are traditionally used in the Philippines as herbal tea. Qualitative phytochemical properties, antibacterial activity, and sensory qualities of herbal tea products from the two species were determined. Analysis showed the presence of alkaloids, carbohydrates, reducing sugars, saponins, phytosterols, phenolics, tannins, flavonoids and proteins and active to very active antimicrobial activity. There were significant differences among the tea products in terms of aroma and taste, flavor intensity and bitterness but no significant differences in term of general acceptability. Brewed herbal tea combined at 1:1 and 2:1 ratios are accepted moderately by regular and non-regular tea drinkers.
\end{abstract}

Keywords: Herbal tea, Sarcandra glabra, Drymis piperita, sensory properties.

\section{Introduction}

Herbal tea is similar to the true tea that is brewed and drink for its benefits. But unlike true tea that come from leaves of Camellia sinensis bush, herbal tea has no caffeine and are prepared from a single or combination of plant parts. Herbal teas are produced depending on purpose which may range from specific to general like relaxation, rejuvenation, cure or relief from some kind of illness/unwanted condition and many other purposes. Medicinally, herbal teas have a reputation for being drunk mainly due to the properties of sedation, relaxation and stimulation. Another reason that people like to drink herbal tea is their therapeutic applications, which has a lot to do with the antioxidant properties of herbal teas.

Among the general benefits from herbal tea include achieving a more calm and relaxed state of mind, supporting heart health, aiding with stomach and digestive problems, providing cleansing properties for the body, promoting energy and wellness, nourishing the nervous system, strengthening the immune system, providing antioxidants to the body, boosting energy levels and invigorating the body, relieving stress, helping to avoid colds, stimulating the internal organs, promoting a good night's sleep among others.

In Ifugao, two species of plants are known to be medicinal and are being used as herbal tea. One is the Drimys piperita Hook. F. (Winteracea) locally known as Hapal in which the fresh or dried young leaves are boil in water and drunk as tea [1]. Another is the Gipas (Sarcandra glabra) which is widely used as tea due to its medicinal value. The health benefits from the above species were reported in some studies on medicinal plants in Ifugao by [2]-[3]-[4].

Reference [5] reported a shrub that is commonly utilized in Benguet and Mt. Province as a beverage tea commonly called as Gipas (Sancandra glabra Thunb.). Gipas is a spreading shrub, $60 \mathrm{~cm}$ to about $1 \mathrm{~m}$ tall. The leaves are oppositely arranged on swollen nodes, toothed, 10 to $15 \mathrm{~cm}$ long and up to $5 \mathrm{~cm}$ wide, leathery in texture, smooth, shiny and pleasantly aromatic when crushed. Flowers are yellowish green while the fruits are about 3 to $4 \mathrm{~mm}$ long, bright red when ripe and contain a single seed. Gipas is widely distributed in the 
Philippines at medium to high elevations. In the Cordillera, Gipas is abundantly found under the humid shades of mossy forests above 1800 meters elevation. The shrub is known for its various medicinal properties. It is used to cure pneumonia, influenza, acute gastroenteritis, appendicitis and post-operative infections, diarrhea, ulcerating wounds, scalds, burns and rheumatic arthritis. It contains fumaric acid, flavonoids, succinic acid, volatile oils and coumarin and can be used for treatment of pancreatic, liver, gastric cancers and leukemias.

Drimys piperata Hook. F. is an evergreen shrub or small tree growing to $4.5 \mathrm{~m}$ (14ft) at a slow rate. It is found only in mossy forest that produce a fruit similar to that of black pepper. Fruits are obovoid to ellipsoid, up to $15 \times 8 \times 7.5 \mathrm{~mm}$, black and nitidous to orange-brown and dull. Leaves are scattered to pseudoverticillate, blades are elliptic or obovate to lanceolate. In the mossy forest of Hungduan, Ifugao, Philippines the plant flowers from late April to early June, and the seeds ripen from October to November. Fruits of those found at the lower portion mature earlier than those found at the upper portion of the mossy forest. The flowers are dioecious (individual flowers are either male or female, but only one sex is to be found on any one plant so both male and female plants can be seen in their habitat. Traditionally leaves are used as tea while the berries are used as antidote, and as anti-diarrheal medicine. Both leaves and berries have peppery flavor.

Owing to the medicinal importance of the species, this study was conducted to produce an herbal tea combining the two species with the hope to maximize benefits derived from the above species.

\section{Procedure}

\subsection{Collection of Plant Materials}

The leaves of healthy plants of Gipas (Sarcandra glabra) and Hapal (Drimys piperita.) were collected in Hungduan, Ifugao, Philippines. Collected leaves were wrapped in moist clean cloth and placed in resealable plastic sheets and were brought to the laboratory for processing. Leaf samples were sent at the Saint Louis University for phytochemical analysis and antimicrobial susceptibility test.

\subsection{Qualitative Phytochemical Screening}

Qualitative phytochemical screening was conducted at the Saint Louis University Natural Science Laboratory following the procedures described by [6] on the leaves of the herbs. The presence of alkaloids in $S$. glabra and D. piperita leaves was determined following the Hager's test. Molisch's test and Fehling's Test were performed in the detection for presence of carbohydrates and reducing sugars. The presence of phytosterols was detected using the Liebermann Burchard's test. Phenolic compounds were detected using the Ferric Chloride test and Gelatin test was used to test the presence of phenolics and tannins respectively. Alkaline Reagent test and Lead Acetate test was conducted for the detection of flavonoids while Xanthoproteic test was used for the detection of protein compounds.

\subsection{Antimicrobial Susceptibility Test}

Antimicrobial susceptibility test was conducted using the disc diffusion method. Agar plates were prepared using $20 \mathrm{ml}$ of sterile Mueller-Hinton agar. Bacterial colonies from a 24 hour culture were suspended in sterile normal saline and standardized with 0.5 M McFarland solution [7]. The surface of the plates was inoculated using a sterile swab containing the standardized saline suspension of bacteria and allowed to dry. Bacteria species used in the study were gram positive Staphylococcus aureus and gram negative Escherichia coli. Sample stock solutions were delivered to a previously prepared sterile paper disks, $6.0 \mathrm{~mm}$ in diameter. The paper discs were allowed to dry and were put on the agar surface. The plates were incubated at 35 degrees Celsius -+ 2 degrees Celsius and observed after 18 hours for clear inhibition zones around the disks. Antimicrobial activity was measured with a diameter zone of inhibition to the nearest millimeters ( $\mathrm{mm}$ ). In interpreting the zone of inhibition, the scale used were as follows: $<10 \mathrm{~mm}$ : Inactive; 10-13 mm: Partially active; 14-19 mm: Active; and, $>19 \mathrm{~mm}$ : Very active. 


\subsection{Production of Herbal Tea}

Collected leaves of $S$. glabra and D. piperita were thoroughly washed to remove adhering particles. The leaves were then wiped with an absorbent towel to drain excess water and were placed in clean drying flat sheets. The leaves in flat sheets were then covered with net to avoid contamination from flies and other contaminants and air-dried in a shaded room with good ventilation for 3 days. The leaves were then ovendried in an oven heated to 30 degrees $\mathrm{F}$ for 10 minutes just to make the leaves crispy but not burned.

The ovendried crispy leaves of each species were then crushed into very fine pieces using blender set at low speed to avoid turning the leaves into powder. Crushed leaves of each species were then stored in clean airtight container.

Herbal tea samples or treatments were then prepared and packed in tea bags by combining and mixing thoroughly the two species with the following ratio:

Treatment A: (1:1) $15 \mathrm{~g}$ S. glabra and $15 \mathrm{~g}$ D. piperita

Treatment B: (2:1) $20 \mathrm{~g}$ S. glabra and $10 \mathrm{~g}$ D. piperita

Treatment C: (1:2) $10 \mathrm{~g}$ S.glabra and 20g D. piperita

\subsection{Experimental Design for Sensory Quality Evaluation}

The experimental design used in the study was completely randomized design (CRD) in 3 trials/replicates. In each treatment $30 \mathrm{~g}$ was brewed in $70^{\circ} \mathrm{C}$ for 5 minutes in a teapot. While it is being brewed, the pot was swirled 10 times. The brewed tea of about $50 \mathrm{ml}$ were poured into pre-warmed tea cups through stainless strainer and were subjected to sensory evaluation. Two groups of evaluators participated in this study. One group compose of regular tea drinkers ( 9 individuals per trial) and the other group composed of non-tea drinkers ( 9 individuals per trial). They evaluated the herbal tea samples/treatments for overall liking/disliking of liquid sparkling quality, liquid color, aroma, flavor intensity, taste, and bitterness using a 3-point scale and general acceptability using a 9-point scale with anchors from dislike extremely to like extremely. Evaluators were provided with mineral water to clean their palate before tasting another herbal tea sample.

\subsection{Statistical Treatment}

The result of the sensory evaluation was collated, tabulated and placed in appropriate tables for statistical analysis. Data were analyzed through Analysis of Variance for completely randomized design (CRD) experiments using statistical software.

\section{Results And Discussion}

\subsection{Phytochemical Constituents of Herbal Tea Plants}

Results of the phytochemical screening of the extract from the leaves of Gipas and Hapal are presented in Table 1. Phytochemical screening of the said extract showed the presence of alkaloids, carbohydrates and reducing sugar, saponins, phytosterols, phenolics, tannins, flavonoids and proteins in the leaf part of S. glabra and D. piperita. Sarcandra glabra leaves contain saponins but were not present in D. piperita leaves, while $D$. piperita leaves contains tannins but were not present in S. glabra leaves. The phytoconstituents detected in the plant materials could be responsible for their antimicrobial activity though their exact mode of action is poorly understood [8].

Alkaloids were found present on the leaves of S. glabra and D. piperita through Wagner's tests and Hager's test respectively. Alkaloids are natural plant compounds that have a basic character and contain at least one nitrogen atom in a heterocyclic ring and having biological activities (beneficial or adverse effects). The true alkaloids are toxic in nature and contain one or more heterocyclic nitrogen compound which is derived from amines and always basic in nature. True alkaloids are normally present in many plants as salts of organic acids. As summarized by [9] from various sources, alkaloids are used as analgesic and sedative and can reduce pain, useful in relieving cough, antihypertensive antineoplastic agents and demonstrate encolytic property (anti-tumor activity), useful in relieving nasal congestion, stopping hemorrhage, stimulating muscles, combating malaria 
and dilating the pupil of the eye. The leaves of S. glabra and D. piperita thus exhibited the potential to cure the illnesses mentioned above.

Carbohydrates and reducing sugars are present in all the plant leaves subjected to analysis. Saponin compounds are present in the leaves of S. glabra but absent in D. piperita. Saponins are a group of naturally occurring plant glycosides, characterized by their strong foam-forming properties in aqueous solution and some kinds of saponins are with strong antitumor effects [10]. The compounds have detergent-like properties that plants produce to help them resist microbial pathogen such as fungi and certain bacteria and viruses. Biological activity of saponins includes hemolytic, expectorative, anti-inflammatory and immune-stimulating activity. Beyond that, saponins demonstrate antimicrobial properties particularly against fungi and additionally against bacteria and protozoa [11].

Phytosterols are present in both S. glabra and D. piperita leavers thru the Libermann Burchard's Test. Phytosterols are any of various sterols derived from plants which are of solid steroid alcohols (as cholesterol) widely distributed in plant lipids. Steroids are any numerous compounds containing a 17-carbon 4-ring system and including the sterols and various hormones and glycosides. Phytosterols which encompass plant sterols and stanols, are steroid compounds similar to cholesterol which occur in plants. Phytosterols play a key role in plant innate immunity against bacterial pathogens by regulating nutrient efflux into the apoplast [12]. Phytosterols compounds from methanol extract and solvent fractions from Lycoris 4adiate exhibited antibacterial activities against Escherichia coli, Staphylococcus aureus [13].

Phenolics are present in the S. glabra and D. piperita plant leaves using the Ferric Chloride Test. Phenolic compounds are aromatic secondary metabolites that impart color, flavor and associated with health benefits such as reduced risk of heart and cardiovascular diseases. Phenolic compounds account for most of the antioxidant activities in plants [14]. Phenolics are compounds possessing one or more aromatic rings with one or more hydroxyl groups. They range from simple molecules like phenolic acids to complex polymerized substances like tannins. Plant phenolics are generally involved in defense against ultraviolet radiation or aggression by pathogens, parasites and predators, as well as contributing to plants' colors [15].

Tannins on the other hand are present in D. piperita leaves thru the Gelatin test but absent in S. glabra. Tannins are water-soluble polyphenols that are commonly found in higher herbaceous and woody plants and are classified into two categories: hydrolysable like tannic acid and non-hydrolysable or condensed tannins like catechin. Some tannins have been reported to have some bactericidal properties which could be attributed to its astringent property which may induce complexation with enzymes or substrates, and the toxic property of tannins as accounted by its ability to complexicate with metal ions [16].

Flavonoids on S. glabra and D. piperita leaves are present using the Alkaline Reagent Test and Lead Acetate Test. According to [17] the most important bioactive compounds are flavonoids which may be responsible for the antibacterial activity of the plant crude extracts of Thymus vulgaris. The same authors further mentioned reports from several authors that flavonoids groups exhibited a wide range of biological activities such as antioxidant, anti-inflammatory, antimicrobial, anti-angionic, anticancer and anti-alergic. In the present study, it is thus suspected that flavonoids and phytosterols must be responsible in its effectiveness as medicine when taken as tea beverage.

Xanthoproteic test revealed that $S$. glabra and D. piperita leaves tested showed the presence of protein compounds. Proteins are the huge group of macromolecules and act as antibiotic and antimicrobial agents. Reference [18] explained that protein recycling could lead to production of smaller proteins important in plant defense activation and other regulatory functions. Glycosides and terpenes were not detected in the leaves of $S$. glabra and D. piperita. 
Table I: Qualitative Phytochemical Properties Of S. GLabra And D. PIPERIta LEaVES

\begin{tabular}{|c|c|c|c|}
\hline Test for Constituents & 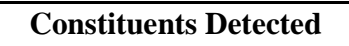 & S. glabra Leaves & D. piperita Leaves \\
\hline \multicolumn{4}{|l|}{ I. Alkaloids } \\
\hline 1. Mayer's Test & Alkaloids & - & - \\
\hline 2. Dragendorff's Test & Alkaloids & - & - \\
\hline 3. Hager's Test & Alkaloids & - & + \\
\hline 4. Wagner's Test & Alkaloids & + & - \\
\hline \multicolumn{4}{|l|}{ II. Carbohydrates } \\
\hline 1. Molisch’s Test & Carbohydrates & + & + \\
\hline 2. Fehling's Test & Reducing Sugars & + & + \\
\hline \multicolumn{4}{|l|}{ III. Glycosides } \\
\hline 1. Modified Borntrager's Test & Anthraquinone glycosides & - & - \\
\hline 2. Kedde Test & Unsaturated lactones & - & - \\
\hline \multicolumn{4}{|l|}{ IV. Saponins } \\
\hline 1. Froth Test & Saponins & + & - \\
\hline 2. Foam Test & Saponins & + & - \\
\hline \multicolumn{4}{|l|}{ V. Phytosterols } \\
\hline 1. Cupric Acetate Test & Diterpenes & - & - \\
\hline 2. Salkowski’s Test & Triterpenes & - & - \\
\hline 3. Liebermann Burchard's Test & Phytosterols & + & + \\
\hline \multicolumn{4}{|l|}{ VI. Phenolic Compounds } \\
\hline 1. Ferric Chloride Test & Phenolics & + & + \\
\hline 2. Gelatin Test & Tannins & - & + \\
\hline \multicolumn{4}{|l|}{ VII. Flavonoids } \\
\hline 1. Alkaline Reagent Test & Flavonoids & + & + \\
\hline 2. Lead Acetate Test & Flavonoids & + & + \\
\hline \multicolumn{4}{|l|}{ VIII. Proteins } \\
\hline 1. Xanthoproteic Test & Proteins & + & + \\
\hline
\end{tabular}

\subsection{Antimicrobial Activity}

Table 2 shows the results of the antimicrobial susceptibility test. Extracts from the leaves of $S$. glabra and $D$. piperita showed varying degree of antibacterial activities against the test of bacterial species. The antimicrobial activities of the extracts were lower than that of two standard antibiotics (Oxacillin and chloramphenicol). The inhibition zone for Staphylococcus aureus was much higher $(16.33-19.67 \mathrm{~mm})$ as compared to Escherichia coli bacteria (12-14.33 mm). Using S. aureus (gram positive) as test bacteria, leaves extract showed the highest zone of inhibition $(19.67 \mathrm{~mm})$. The results imply that leaves extract is very active in inhibiting the growth of $S$. aureus. The antibacterial activity of the extracts was attributed to presence of alkaloids, flavonoids, and phenolic compounds [19]. The higher zone of inhibition by leaf extract could be attributed to the presence of coumarin compounds that showed strong cytotoxic activity [20] and Mahanine, a carbazole alkaloid with high antimutagenic activity [21].

Using E. coli (gram negative) as test bacteria, leaves extract showed the highest zone of inhibition (14.33 $\mathrm{mm})$. The results imply that leaves extract is active. The findings further imply that E. coli is more resistant to inhibitory effect of extracts from $D$. piperita leaves. Findings in this study was also similar to the findings of [22] wherein Staphylococcus aureus was the most susceptible isolate tested while Escherichia coli was the least susceptible isolate to extracts from Citrus aurantifolia (Lime fruit). The findings were also comparable to that of [23] in which crude extract of Cinnamomum mercadoi has moderate activity (11.05 $\mathrm{mm}$. zone of inhibition) against $S$. aureus and no activity was exhibited against E. coli. As explained by [24], the outer membrane of gram negative bacteria contains glycolipid lipopolysaccharides which act as a protective wall, rendering bacteria resistant to a variety of host defense molecules and antimicrobial compounds than gram negative bacteria. In other words, the cell wall of gram negative bacteria is more complex than gram positive bacteria which make it 
more impermeable [25]. Therefore, this explains why the gram negative bacteria were more resistant to antimicrobial compounds with its effective diffusion barrier. According to [26], antibacterial activity of Cinnamomum leaf extract with concentration $0.1 \mathrm{~g} / \mathrm{ml}$ could replace the role of tetracycline to inhibit Salmonella sp, but to inhibit Escherichia coli higher concentration was needed.

The method of extraction has influence on antimicrobial properties of plant extract. Reference [26] found that methanol extract was more effective than the ethanol extract against all the organisms while water extract showed low or non-active antibacterial activity in most organisms. Reference [27] however found that among the different extracts, acetone and hexane extracts were found to exhibit maximum growth inhibition compared to methanolic and ethanolic extracts suggesting the antimicrobial activity is stronger with non-polar fractions compared to polar fractions. In this study, only methanol extract was used which may partly explain the relatively high biological activity of the extracts from $S$. glabra and D. piperita leaves.

The above antimicrobial activity $S$. glabra and D. piperita indicate their great therapeutic potential justifying their use as herbal medicine.

TABLE II: Zone OF Inhibition As AfFected By Gipas LeAves Plant PART EXtracts Using Disc Diffusion MethoD

Sample Treatment

A. S. Glabra

1. Test bacteria: Staphylococcus aureus Leaves Extract Oxacillin (1 ug)

2. Test bacteria: Escherichia coli

Leaves Extract

Chloramphenicol (30ug)

\section{B. D. Piperita}

1. Test bacteria: Staphylococcus aureus Leaves Extract Oxacillin (1 ug)

2. Test bacteria: Escherichia coli Leaves Extract

Chloramphenicol (30ug)
Replication (Zone of Inhibition measured in $\mathrm{mm})^{*}$

I

9

II

20

32

32

13

26

14

32

13

26
Mean (mm)

III

20

32

12

26

12

26

26

Interpretation

$\begin{array}{ccc}19.67 & \text { Very Active } \\ 32 & 32 & \end{array}$

$12 \quad$ Partially active


The significant difference can be attributed to the greater amount of Gipas (Sarcandra glabra) in treatment B where in 2:1 ratio of $S$. glabra-D. piperita was used. S. glabra has a strong fragrant odor compared to D. piperita.

Flavor Intensity. In terms of flavor intensity, data shows that treatment B got the highest mean which is 2.44 , followed by treatment A (2.41) and treatment C (2.04) All treatments are moderately strong flavor description but analysis of variance showed significant differences in terms of flavor intensity.

Taste. Table III also shows the sensory evaluation of the different prepared tea treatments in terms of taste. Treatment B had the highest score (2.67) followed by treatment A (2.59) but both had the same description of "Very distinct herb-like taste." Treatments C with a score of 2.07 is described as "Moderately herb-like taste." Data analysis shows that there are significant differences in terms of taste in which treatments A and B have significantly very distinct taste compared to treatment $\mathrm{C}$. The significant differences in terms of taste could be attributed to the variation on the ratio used in the preparation of treatments.

Bitterness. Data shows that treatment $\mathrm{C}$ got the highest score of 2.41 followed by Treatments A and B with a mean score of 2.33 and 1.74, respectively. All treatments fall under the "moderate" description in terms of bitterness. However analysis showed significant differences among the treatments $(P-0.001)$.

General Acceptability. Using the hedonic scale to interrupt the result, it was found that treatments A and B fall under the "like moderately" category while treatment $\mathrm{C}$ fall under "like slightly" by the evaluators. This mean that the indigenous herbal plants namely Gipas (Sarcandra glabra) and Hapal (Drimys piperita.) when processed into herbal tea at 1:1 and 2:1 ratios are more preferred by non-tea drinker. The analysis of variance however showed no significant differences among the treatments $(P-0.512)$ implying that all the treatments have the same in their level of acceptability.

TABLE III: SENSORY EVALUATION AND GENERAL ACCEPTABILITY ACCORDING NON-TEA DRINKERS

\begin{tabular}{|c|c|c|c|c|c|}
\hline \multirow{2}{*}{\multicolumn{2}{|c|}{ Parameters }} & \multicolumn{3}{|c|}{ Treatments } & \multirow[t]{2}{*}{ P-Value } \\
\hline & & $\begin{array}{c}\text { A } \\
(1: 1 \text { ratio })\end{array}$ & $\begin{array}{c}\text { B } \\
(2: 1 \text { ratio })\end{array}$ & $\begin{array}{c}C \\
(1: 2 \text { ratio })\end{array}$ & \\
\hline \multicolumn{2}{|l|}{ Sparkling quality } & $2.11^{\mathrm{ns}}$ & $2.30^{\mathrm{ns}}$ & $2.22^{\mathrm{ns}}$ & 0.414 \\
\hline \multirow{3}{*}{ Liquid color } & Description & Moderately sparkling & Moderately sparkling & $\begin{array}{l}\text { Moderately } \\
\text { Sparkling }\end{array}$ & \\
\hline & & $2.33^{\mathrm{ns}}$ & $2.37^{\mathrm{ns}}$ & $2.15^{\mathrm{ns}}$ & 0.652 \\
\hline & Description & Light brown & Light brown & Light brown & \\
\hline Aroma & & $2.48^{\mathrm{a}}$ & $2.52^{\mathrm{a}}$ & $2.11^{\mathrm{b}}$ & 0.002 \\
\hline Flavor Intensity & Description & $\begin{array}{c}\text { Moderately fragrant } \\
2.41^{\mathrm{a}}\end{array}$ & $\begin{array}{c}\text { Very fragrant } \\
2.44^{\mathrm{a}}\end{array}$ & $\begin{array}{c}\text { Moderately fragrant } \\
2.04^{\mathrm{b}}\end{array}$ & 0.001 \\
\hline \multirow[t]{2}{*}{ Taste } & Description & $\begin{array}{l}\text { Moderately strong flavor } \\
2.59^{\mathrm{a}}\end{array}$ & $\begin{array}{c}\text { Moderately strong flavor } \\
2.67^{\mathrm{a}}\end{array}$ & $\begin{array}{c}\text { Moderately strong flavor } \\
2.07^{\mathrm{b}}\end{array}$ & 0.001 \\
\hline & Description & $\begin{array}{l}\text { Very distinct herb like } \\
\text { taste }\end{array}$ & $\begin{array}{l}\text { Very distinct herb like } \\
\text { taste }\end{array}$ & $\begin{array}{l}\text { Moderately distinct herb } \\
\text { like taste }\end{array}$ & \\
\hline \multirow[t]{2}{*}{ Bitterness } & & $2.33^{\mathrm{a}}$ & $1.74^{\mathrm{b}}$ & $2.41^{\mathrm{a}}$ & 0.0001 \\
\hline & Description & moderate & moderate & moderate & \\
\hline \multicolumn{2}{|c|}{ General Acceptability } & $7.11^{\mathrm{ns}}$ & $7.44^{\mathrm{ns}}$ & $6.49^{\mathrm{ns}}$ & 0.512 \\
\hline & Description & Like moderately & Like moderately & Like slightly & \\
\hline
\end{tabular}

\subsection{Herbal Tea Evaluation by Regular Tea Drinkers}

Liquid Sparkling Quality. Table IV shows the sensory evaluation of the different herbal tea treatments in terms of liquid sparkling quality based on evaluation or regular tea drinkers. Treatment $\mathrm{B}$ got the highest mean of 2.00 followed by treatment C (1.96) and treatment A (1.93). Despite their numerical differences, all the treatments are described as "moderately sparkling" and statistical analysis showed no significant differences among the treatments $(P-0.842)$.

Liquid Color. Result shows that Treatment $\mathrm{C}$ has the highest mean among the four treatments followed by treatments A, and B. All treatments fall under the "Light Brown' liquid color and are statistically at par with each other $(P-0.324)$ implying that the evaluators gave more or less the same color description. 
Aroma. Between treatments, treatment A got the highest mean of 2.41, followed by treatment B (2.19) and treatment C (2.15). All treatments are "moderately fragrant" and are statistically the same $(P-0.135)$.

Flavor Intensity. The result of evaluation of herbal tea samples in terms of flavor intensity showed that treatments A and B with a mean score of 2.63 and 2.56, respectively had the highest mean with "strong flavor" followed by treatment $\mathrm{C}$ (2.33) with "moderately strong flavor." The analysis of variance shows significant differences among the treatment in terms of flavor intensity $(P-0.002)$ implying that treatments $\mathrm{A}$ and $\mathrm{B}$ are significantly stronger in terms of flavor intensity compared to treatments $\mathrm{C}$ but are statistically at par with each other.

Taste. Treatment A was judged by evaluator with "Very distinct herb like taste" description with the highest mean score of 2.52. This taste could be the result of the balance combination of S. glabra and D. piperita in the preparation of tea sample. Treatments B (2.37) and C (2.37) were evaluated as "Moderately distinct herb-like taste." Statistical analysis however showed no significant differences among the treatments $(P-0.142)$.

Bitterness. The results of evaluation in terms of herbal tea bitterness revealed that treatment $\mathrm{C}$ got the highest mean of 2.52 which is "strong" in terms of bitterness. The strong bitterness in treatment $\mathrm{C}$ could be attributed to the presence of tannins in D. piperita with bitter properties and the greater amount of D. piperita used in the preparation of herbal tea samples. Treatment A has a mean of 2.13 followed by treatment B (2.03) and are described as "moderate" in terms of bitterness. Statistical analysis shows that there is a significant differences in terms of bitterness among the three treatments $(P-0.003)$.

General Acceptability. The general acceptability of herbal tea samples as evaluated by regular tea drinkers shows that treatments A and B are "like moderately" while treatment C is "like slightly." The moderate and slight likeliness evaluation of the herbal tea samples maybe due to unfamiliarity of the regular tea drinkers to the newly formulated herbal tea compared to the usual tea they have been drinking.

The analysis of variance made in the general acceptability of the treatments revealed no significant differences $(P-0.615)$, although herbal tea made from Sarcandra glabra and Drimys piperita at 1:1 and 2:1 ratios were accepted moderately and herbal tea prepared at 1:2 ratio was accepted slightly by regular tea drinkers.

TABLE IV: SENSORY EVALUATION AND GENERAL ACCEPTABILITY ACCORDING REGULAR TEA DRINKERS

\begin{tabular}{|c|c|c|c|c|c|}
\hline \multirow[b]{2}{*}{ Parameters } & & \multicolumn{3}{|c|}{ Treatments } & \multirow[t]{2}{*}{ P-Value } \\
\hline & & $\begin{array}{c}\mathrm{A} \\
(1: 1 \text { ratio })\end{array}$ & $\begin{array}{c}\mathrm{B} \\
(2: 1 \text { ratio })\end{array}$ & $\begin{array}{c}\mathrm{C} \\
(1: 2 \text { ratio }) \\
\end{array}$ & \\
\hline \multirow[t]{2}{*}{ Sparkling quality } & & $1.93^{\mathrm{ns}}$ & $2.00^{\mathrm{ns}}$ & $1.96^{\mathrm{ns}}$ & 0.842 \\
\hline & Description & Moderately Sparkling & Moderately Sparkling & Moderately Sparkling & \\
\hline \multirow[t]{2}{*}{ Color } & & $1.67^{\mathrm{ns}}$ & $1.59^{\mathrm{ns}}$ & $1.96^{\mathrm{ns}}$ & 0.324 \\
\hline & Description & Light Brown & Light Brown & Light Brown & \\
\hline \multirow[t]{2}{*}{ Aroma } & & $2.41^{\mathrm{ns}}$ & $2.19^{\mathrm{ns}}$ & $2.15^{\mathrm{ns}}$ & 0.135 \\
\hline & Description & $\begin{array}{l}\text { Moderately } \\
\text { Fragrant }\end{array}$ & $\begin{array}{l}\text { Moderately } \\
\text { Fragrant }\end{array}$ & $\begin{array}{l}\text { Moderately } \\
\text { Fragrant }\end{array}$ & \\
\hline \multirow[t]{2}{*}{ Flavor Intensity } & & $2.63^{\mathrm{a}}$ & $2.56^{\mathrm{a}}$ & $2.33^{\mathrm{b}}$ & 0.002 \\
\hline & Description & $\begin{array}{l}\text { Strong } \\
\text { Flavor }\end{array}$ & $\begin{array}{l}\text { Strong } \\
\text { Flavor }\end{array}$ & $\begin{array}{c}\text { Moderately } \\
\text { Strong } \\
\text { Flavor }\end{array}$ & \\
\hline \multirow[t]{2}{*}{ Taste } & & $2.52^{\mathrm{ns}}$ & $2.37^{\mathrm{ns}}$ & $2.37^{\mathrm{ns}}$ & 0.142 \\
\hline & Description & Very distinct herb-like taste & $\begin{array}{l}\text { Moderately distinct herb- } \\
\text { like taste }\end{array}$ & $\begin{array}{l}\text { Moderately distinct herb- } \\
\text { like taste }\end{array}$ & \\
\hline \multirow[t]{2}{*}{ Bitterness } & & $2.13^{b}$ & $2.03^{\mathrm{b}}$ & $2.52^{\mathrm{a}}$ & 0.003 \\
\hline & Description & Moderate & Moderate & Strong & \\
\hline \multicolumn{2}{|c|}{ General Acceptability } & $6.85^{\mathrm{ns}}$ & $6.85^{\mathrm{ns}}$ & $6.44^{\mathrm{ns}}$ & 0.615 \\
\hline & Description & $\begin{array}{c}\text { Like } \\
\text { Moderately }\end{array}$ & $\begin{array}{c}\text { Like } \\
\text { Moderately }\end{array}$ & $\begin{array}{l}\text { Like } \\
\text { Slightly }\end{array}$ & \\
\hline
\end{tabular}




\section{Conclusions}

Phytochemical contents common to leaves of S. glabra and D. piperita include alkaloids, carbohydrates, reducing sugar, phytosterols, phenolics, flavonoids and proteins. Leaves of Sarcandra glabra further contains saponins that is absent in Drimys piperita while tannins are present in D. piperita but absent in S. glabra. The antimicrobial activities of the extracts from leaves indicated very active to active effect against gram positive bacteria (Staphylococcus aureus) and active to partially active against gram negative bacteria (Escherichia coli).

Herbal tea brewed from $S$. glabra and D. piperita prepared at 1:1 and 2:1 ratios have stronger aroma and flavor intensity with moderate bitterness and were moderately accepted while herbal tea prepared at 1:2 ratio has strong bitterness and was slightly accepted by regular and non-tea drinkers. Therapeutic potentials of the herbal tea product needs further investigation.

\section{Acknowledgment}

Sincere acknowledgment is due to the Ifugao State University Administration for funding the conduct of this study and to all who extended their assistance and support for the completion of this study.

\section{References}

[1] L.P. Pladio and I.M. Villaseñor, Isolation and characterization of TIHE principle in Drimys piperita hook $f$. (Sapal) that could lead to the symptomatic relief of diarrhea. BSU, 2004.

[2] B. Bantiyan, Phytochemical screening of selected herbal plants in Ifugao, The Upland Farm Journal, 2007, 18(1), 62-74.

[3] N.A.P. Gonzales, Indigenous medicinal uses and phytochemical analysis of Native Angel Wing Begoniales (Nangol), The Upland Farm Journal, 2011, 20(1), 82-90.

[4] N.K. Taguiling, Macrofloral biodiversity conservation in Ifugao. European Scientific Journal, Special Edition, 2013, 4, 1857-7881

[5] PCAARRD (2006). Sarcandra glabra Thumb. PCAARRD Files. 2006. http://www.pcaarrd.dost.gov.ph/home/ momentum/afin/index.php?option=com_content\&view=article\&id=404\&catid=87\&Itemid=2

[6] P.S. Tiwari, S. Kumar, G. Kaur, H. Kaur, H., and M. Kaur, Phytochemical screening and Extraction: A Review, Internationale Pharmaceutica Sciencia, 2011, 1(1), 98-106.

[7] A. Muhammad, and S.Y. Mudi, Phytochemical screening and antimicrobial activities of Terminalia catappa, leaf extracts. Biokemistri, 2011, 23(1), 35-39.

[8] G.J. Kaur, and D.S. Arora, Antibacterial and phytochemical screening of Anethum graveolens, Foeniculum vulgare and Trachyspermum ammi, BMC Complementary and Alternative Medicine, 2009, DOI: 10.1186/1472-6882-9-30

[9] S.E.S. Banes, and L. Castor, Phytochemical and pesticidal properties of Barsanga (Cyperus rotundus Linn.) JPAIR Multidisciplinary Journal, 2011, 6(1), 197-214.

[10] S. Man, W. Gao, L. Zhang, L. Huang, and C. Liu, Chemical study and medical application of saponins as anti-cancer agents, Fitoterapia, 2010, 81(7), 703-714.

[11] J.C. Hembree, Benefits of Saponins. 2015. http://medicalmarijuana.com/experts/expert/title.cfm?artID=945

[12] K. Wang, M.S. Kumar, L. Kang, and K.S. Mysre, Phytosterols play a key role in plant innate immunity against bacterial pathogens by regulating nutrient efflux into the apoplast, Plant Physiology, 2012, 158(4), 1789-1802.

[13] D.G. Lee, A.Y. Lee, S-J. Kim, Y-S. Jung, D-H. Lee, E.U. Cho, and S. Lee, Antibacterial phytosterols and alkaloids from Lycoris radiate, Natural Product Sciences, 2014, 20(2), 107-112.

[14] Z. Khanam, C.S. We, and I.U.H. Bhat, Phytochemical screening and antimicrobial activity of root and stem extracts of wild Eurycoma longifolia Jack (Tongkat Ali), 2015. 
[15] J. Dai, and R.J. Mumper, Plant phenolics: Extraction, analysis and their antioxidant and anticancer properties, Molecules, 2010, 15, 7313-7352. [13] Lee, D.G. Lee, A.Y., Kim, S-J, Jung, Y-S., Lee, D-H, Cho, E-U \& S. Lee (20014) Antibacterial phytosterols and alkaloids from Lycoris radiate, Natural Product Sciences, 2014, 20(2), $107-$ 112.

[16] H. Akiyama, K. Fujii, O. Yamasaki, O. Oono, and K. Iwatsuki, Antibacterial action of several tannins against Staphylococcus aureus. Journal of Antimicrobila Chemotherapy, 2001, 48(4), 487-491.

[17] M.A. Hossain, K.A.S. AL-Raqmi, Z-W. AL-Mijizy, A.M. Weli, and Q. Al-Riyami, Study of total phenol, flavonoids contents and phytochemical screening of various leaves crude extracts of locally grown Thymus vulgaris, Asian Pac. J. Trop. Biomed, 2013, 3(9), 705-710.

[18] W.A. Vargas, J.M. Martin, G.E. Rech, L.P. Rivera, J.M. Diaz-Minquez, M.R. Thon, M.R. and S.A. Sukno, Plant Defense Mechanisms Are Activated during Biotrophic and Necrotrophic Development of Colletotricum graminicola in Maize, Plant Physiology, 2012, 158(3), 1342-1358.

[19] M. Faisal, M.M.H. Sarker, A. Rahman, A.I. Hossain, S. Rahman, Murraya paniculata (L.) Jack: A Potential Plant for Treatment of Toothache, J. Dent. Oral Disord. Ther.,2013, 2(3), 1-3

[20] M. Rahmani, R.A. Susidarti, H.B.M. Ismail, M.A. Sukari, T. Yap, Y. Hin, YG.E.C. Lian, and A.M. Ali, Cytotoxic activity of coumarins from Micromelum minutum. Pharmaceutical Biology, 2009, 47 (2), 182-185.

[21] K. Nakahara, G. Trakoontivakorn, N.S. Alzoreky, H. Ono, M. Onishi-Kameyama, and M. Yoshida, Antimutagenicity of some edible Thai plants, and a bioactive carbazole alkaloid, mahanine, isolated from Micromelum minutum, J. Agric. Food. Chem, 2002, 50 (17), 4796-4802.

[22] T. Aibinu, T. Adenipekun, T. Adelowaton, T. Ogunsanya, and T. Odugbemi, Evaluation of the Antimicrobial properties of different parts of Citrus Aurantifolia (Lime Fruit) as used locally, African Journal of Traditional, Complementary, and Alternative Medicines,2007, 4(2), 185-190.

[23] R.C.Torres, F.M. Sison, and MC. Ysrael, Phytochemical screening and biological studies on crude methanol extract of Cinnamomum Mercadoi, Vidal, Philippine Journal of Science, 2001, 132 (1), 27-32.

[24] N. Papo, N. and Y. Shai, A molecular mechanism for Lipopolysaccharide protection of gram-negative bacteria from antimicrobial peptides, The Journal of Biological Chemistry, 2005, 280(11), 10378-10387.

[25] K.Y. Wong, P. Vikram, and K.K. Chiruvella, Phytochemical screening and antimicrobial potentials of Borreria sps (Rubiaceae), Journal of King Saud University - Science, 2014, 27, 302-311.

[26] A. Yuniza and Yuherman. Contents of phytochemical compound and antimicrobial activity of Cinnamom Leaf (Cinnanmomum burmani) and Noni fruits and leaf (Morinda citrifolia L.)

[27] O.O. Igbinosa, E.O. Igbinosa, and O.A. Aiyegoro, Antimicrobial activity and phytochemical screening of stem bark extracts from Jatropha curcas (Linn), African Journal of Pharmacy and Pharmacology, 2009, 3(2), 058-062. 